\title{
Isolation and Structure Elucidation of Bioactive Compounds Chemical as Inhibitors of the Enzyme A-Glucosidase Raru Bark Ethanol Extract (Vatica pauciflora Blume)
}

\author{
Ida Duma Riris ${ }^{1}$, Tonel Barus ${ }^{2}$, Partomuan Simanjuntak ${ }^{3} \&$ Basuki Wirjosentono $^{2}$ \\ ${ }^{1}$ Faculty of Mathematics and Natural Sciences, State University of Medan, Indonesia \\ ${ }^{2}$ Faculty of Mathematics and Natural Sciences, North Sumatera University, Medan Indonesia \\ ${ }^{3}$ Research Centre for Biotechnology, Indonesian Institute of Sciences (LIPI), Cibinong Indonesia \\ Correspondence: Ida Duma Riris, Faculty of Mathematics and Natural Sciences, State University of Medan, \\ Indonesia. E-mail: dumariris@gmail.com
}

Received: January 5, 2014 Accepted: February 11, 2014 Online Published: March 6, 2014

doi:10.5539/ijc.v6n2p15 URL: http://dx.doi.org/10.5539/ijc.v6n2p15

\begin{abstract}
Inhibitory compound of $\alpha$-glucosidase bioactivity was isolated from ethanol extract of the stem bark of raru (Vatica pauciflora Blume) which, is a wild plant that grows in Tapanuli state in Indonesia. The ethanol extract of the stem bark of raru was partitioned and was chromatographed on columns with stationare fase silica gel 60 mesh $\mathrm{F}_{254}(0.063 \mathrm{~mm}-0.200 \mathrm{~mm})$. The ethanol extract of isolates showed the enzyme $\alpha$-glucosidase inhibitor $\mathrm{IC}_{50}$ of 93.46. The next step is the determination of the chemical structure of the Ultraviolet-visible spectroscopy (UV Vis); FT-IR (Fourier Transform Infrared spectroscopy), NMR (Nuclear Magnetic Resonance) namely COSY, Heteronuclear Multiple-Quantum Correlation (HMQC); and Heteronuclear Multiple-Bond Correlation (HMBC). It found of compounds consist of two of methoxy, one of aromatic, and one of carbonil compounds. The isolat is a 3,4,9, Trihidroxy-2-(hydroxymethyl)-8-10-dimethoxy-2-3-4atetrahydropyrano(3,2-c)isochromen-6(10bH)-one acording to International Union of Pure and Applied Chemistry (IUPAC).
\end{abstract}

Keywords: raru (Vatica pauciflora Blume), antidiabetic, $\alpha$-glucosidase inhibitor

\section{Introduction}

The use of traditional medicine is Indonesian culture that goes back thousands years ago. It is a cultural heritage of Indonesia that need to be explored, researched, and developed (Hedi, 2007). Consumed plant extracts for the treatment, which is made in the form of decoction, herbal remedies and herbal capsule form. Things like this do to treat diabetic mellitus. Diabetic Mellitus (DM) is a condition of the concentration of glucose in the blood is chronically higher than normal value (hyperglycemia). This is caused by a deficiency of insulin or the insulin does not function effectively. Diabetic can lead to various diseases such as hypertension, stroke, coronary heart disease, and kidney failure (Guyton \& Hall, 2007).

Measurement of glucose levels can be determined in vitro by enzymatic methods (Lucile, 1997). Spectrophotometer for color intensity is used hereinafter blood glucose levels can be determined.

According to World Health Organization (2005), more than $80 \%$ of the population in developing countries consume natural ingredients derived mainly from plants, either as a form of maintaining health and medicine. The use of natural medicine is intended to avoid the side effects of chemical drugs. And plant-based treatments currently has a market share of about $30 \%$.

Adebayo (2008) found extracts of plants as antidiabetic impact activities such as: Vermonia amygdalina, Bidens pilosa, Carica papaya, Citrus aurantiifolia, Ocimumgratisimum, Momordica charantia and Morindalucida these plants have been consumed in Nigeria.

Likewise Gunawan (2009) discovered a flavonoid in four raru plant species, namely (1) CotylelobiummelanoxylumPierre, (2) Shoreabolancarpoides Symington, (3) Cotylelobiumlanceolatumcraib, and (4) Pierre Cotylelobiummelanoxylon be expressed that these compounds can lower blood sugar levels in vitro.

There are three compounds that have activity flafonoid as antidiabetic, namely (1) 3- $\beta$-hydroxynaringenin or 
isoaromadendrin, (2) taxifolin, and (3) 5-hydroxy-3, 4', 7 trimethoxiflavonone. Flavonoids extracted with ethanol. Compounds 1 and 2 were found from plant Euphorbia cuneata Vahl, and compounds to the three found in the ethanol extract of Salvia L. verbenaca Flavonoids were identified by spectroscopic data ${ }^{1} \mathrm{H},{ }^{13} \mathrm{C}$ NMR, DEPT, COSY, HMQC and Nuclear Overhauser effect spectroscopy (NOESY) (Bahar, 2005). Isolation of ethyl acetate extract from the leaves of plants Arto carpus communis flavonoid found to have activity as an antidiabetic, ie 8-geranyl-4,5,7-flavone trihidroksi. This can inhibit $\alpha$-glucosidase enzyme $\mathrm{IC}_{50} 18.12 \mathrm{pg} \mathrm{mL}^{-1}$ (Puspa, 2008).

In the ethanol extract of the stem bark raru contained flavonoids are phytochemicals. Antidiabetic bioactivity barrier test conducted by Ida (2013) in vitro against hexane, ethyl acetate, ethanol, and water from the plant stem bark raru (Vatica pauciflora blume), obtained bioactivity of $\alpha$-glucosidase inhibition of ethanol extract of the stem bark extract is higher than ethyl acetate, hexane and water by using acarbose as a control. In this study bark raru types Vatica pauciflora Blume extracted, and further testing of the inhibitory activity against enzima-glucosidase. Toxicity tests conducted by Brine Shrimp Lethality Test (BSLT). Further isolation and elucidation performed on extracts that have inhibitory activity of $\alpha$-glucosidase enzyme of the most high. The chemical structure determined by spectroscopic spectral data (UV, FT IR1, NMR1D, 2D NMR, COSY, HMQC, HMBC), and HR MS.

\section{Methods and Materials}

Raru bark samples (Vatica pauciflora blume) extracted by solvent extraction method, that stratified by different levels of polarity, namely n-hexane, ethyl acetate, $96 \%$ ethanol, and water. Each extract was concentrated, tested toxicity with BSLT method. With this method, the toxicity of a compound with $\mathrm{LC}_{50}$ value is the concentration of the compound that gives as much as $50 \%$ mortality rate. Active compounds will provide a high mortality. The smaller the value, the greater the toxicity $\mathrm{LC}_{50}$. A sample said to be highly toxic to shrimp larvae when Artemiasalina Leach has $\mathrm{LC}_{50}<30 \mathrm{mg} / \mathrm{mL}$. $\mathrm{LC}_{50}$ has declared toxic when $30-1000 \mathrm{mg} / \mathrm{mL}$ and less toxic when having $\mathrm{LC}_{50}>1000 \mathrm{mg} / \mathrm{mL}$ (Steven \& Russell, 1993).

Bioactivity inhibition of the enzyme $\alpha$-glucosidase carried out in vitro by the method of Kawanishi, that inhibition of solving the model substrate $p$-nitrophenol- $\alpha$-D-glucopyranosid to p-nitrophenol and glucose yellow. The enzyme activity was measured based on the absorbance of p-nitrophenol right generated by UV-visible spectrophotometry at $\lambda 400 \mathrm{~nm}$ (Matsui, 2001). Phytochemical test was conducted using Harborn method. Extract that has the highest bioactivity separated by column chromatography. The shape of the stem bark raru extraction scheme shown in Figure 1.

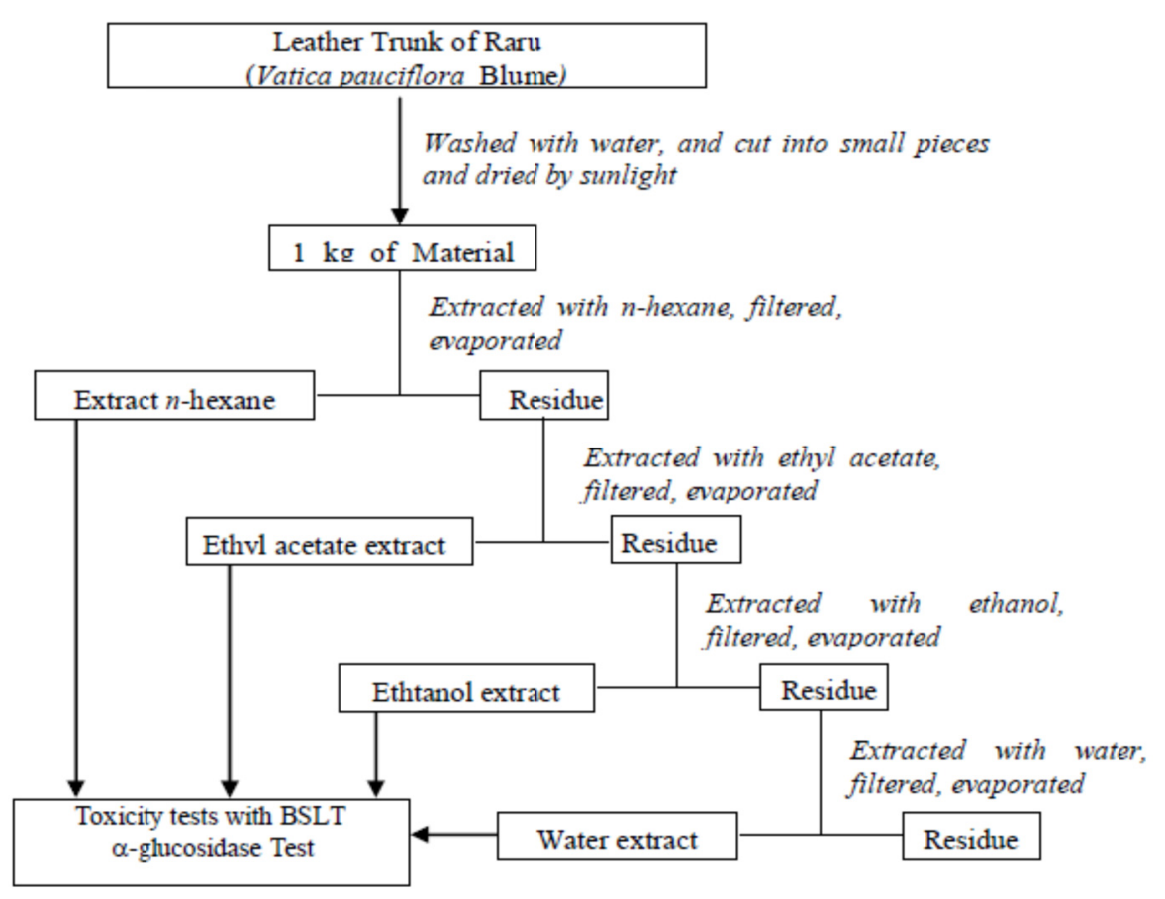

Figure 1. Extraction scheme, fractionation of the stem bark of raru (Vatica pauciflora) 


\subsection{Fractionation by Column Chromatography Method}

Extract ethanol fractionation by chromatography column I, performed by taking as much as $5.0 \mathrm{~g}$ of ethanol extract, and further fractionated by column chromatography using silica gel stationary phase $60 \mathrm{mesh}$. And the mobile phase used was chloroform-methanol (40:1 1:1). The compounds in botanicals, grouped by polarity in the form of fractions. To obtain a more simple fractions, done by combining fractions that have the same pattern of the chromatogram. Results fractions of column 1 are combined into 14 fractions, and then tested the inhibition of the enzyme $\alpha$-glucosidase. The test results showed inhibition of the enzyme $\alpha$-glucosidase is the fraction 9 .

Extract ethanol fractionation by column chromatography II made to the fraction 9 that the same method as in column I. Results fractions were combined, and obtained six fractions, were then tested for inhibition against $\alpha$-glucosidase enzyme.

Further separation of fraction VPEt-9 with chromatography columns III conducted in fractions 9-4 with the same method as in column I. Results fractions were combined and gained 5 fractions. Tests conducted on the inhibition of the enzyme $\alpha$-glucosidase. Provided that fractions 9-4 VPEt-4 of the ethanol extract had $\alpha$-glucosidase inhibitory activity of the most high, and further separated by column chromatography. This was done to obtain a pure compound.

Purity test using 2-dimensional TLC performed on fractions VPEt-9-4-4 obtained from test results antidiabetic. Analysis was performed using silica gel stationary phase $\mathrm{GF}_{254}$ plates with a mobile phase of chloroform-methanol (2:1), and chloroform-acetonitrile (2:1). Chemical structure determination carried out by UV-Vis spectroscopy, FT-IR, NMR analysis (1H.13C-NMR and DEPT) and 2D NMR (COSY, HMQC, HMBC), and the number of isolates VPEt-9-4-4 reconstituted with $\mathrm{CD}_{3} \mathrm{OD}$.

\section{Results}

The yield of extraction results shown in Table 1, where the highest obtained in the extraction of ethanol.

Table 1. The results of the yield of the extract of the stem bark of raru (Vatica pauciflora Blume)

\begin{tabular}{lcc}
\hline Sample & Weight $\mathbf{( g )}$ & The yield of $(\mathbf{\%}) *$ \\
\hline$n$-hexane & 6,21 & 0,62 \\
Ethylacetate & 58,62 & 5,86 \\
Ethanol & 76,13 & 7,61 \\
Distilled water & 19,47 & 1,95 \\
\hline
\end{tabular}

Description: * 1 kg calculated on the dry crude drug.

The result of extract toxity test of $n$-Hexane, ethylacetate, ethanol and water and water by BSLT method, each of them is n-hexane extract $\mathrm{LD}_{50}=368,51 \mathrm{ppm}$, ethylacetate $=19,45$, ethanol $=5,76 \mathrm{ppm}$, dan air $=36,22 \mathrm{ppm}$. It shown that ethanol extract has the least toxity. The results of Antidiabetic test of each extract by $\alpha$-glucosidase inhibitory method is shown in Table 2.

Table 2. Test results antidiabetic extract using an enzyme inhibition method aglucosidase

\begin{tabular}{|c|c|}
\hline Extract & Inhibisi (\%) \\
\hline$n$-hexane & 28,98 \\
\hline Ethylasetate & 60,83 \\
\hline \multicolumn{2}{|c|}{ 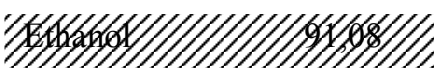 } \\
\hline Water & 78,34 \\
\hline
\end{tabular}

Phytochemical test results on ethanol extract of bark which has bioactivity antidiabetic raru highest, with Harborn method, indicates that there are flavonoids, saponins, quinones, tannins, triterpenoids, essential oil, and coumarin.

The results of the analysis of NMR (Nuclear Magnetic Resonance) 1-dimensional (1H and 13C-NMR) is based 
on Silverstein (1991). Proton spectra $\left({ }^{1} \mathrm{H}-\mathrm{NMR}\right.$ and carbon $\left({ }^{13} \mathrm{C}-\mathrm{NMR}\right)$ was done by dissolving the samples in deutereum methanol $\left(\mathrm{CD}_{3} \mathrm{OD}\right)(0.5 \mathrm{~mL})$, respectively in the NMR tube $(5 \mathrm{~mm})$. Spectra were recorded on a JEOL 500 spectrophotometer ( $\left({ }^{1} \mathrm{H}-\mathrm{NMR} \mathrm{MHz}\right.$ and ${ }^{13} \mathrm{C}-\mathrm{NMR}$ at $\left.125 \mathrm{MHz}\right)$.

1H-NMR spectra of ethanol extracts to isolate 9-4-4-1. Proton nuclear magnetic resonance spectra (1H-NMR) indicate the type and number of protons contained in the ethanol extract of isolates 9-4-4-1. Proton methoxy $\left(\mathrm{OCH}_{3}\right)$ in the area of chemical shift (chemical shift) $\delta \mathrm{H} 3.87$ and $3.97(3 \mathrm{H})$ in the singlet splitting pattern (s). Some metin proton $(\mathrm{CH})$ are the chemical shifts $\delta \mathrm{H} 3.53 ; 3.54 ; 3.77 ; 3.82 ; 3.96 ; 3.99$, and 4.80 , which is characteristic for the protons that resonate with the oxygen atom, and one olefinic proton at $\delta \mathrm{H}$ metin that 7,32 (s), which does not resonate with other protons.

13C-NMR spectra To Isolate 9-4-4-1. 13C-NMR spectra and DEPT experiments analysis (Distortionless Enhancement by Polarization Transfer) shows there are 15 carbon on the chemical structure of the ethanol extract had inhibition against $\alpha$-glucosidase enzyme highest as shown in Figure 2.

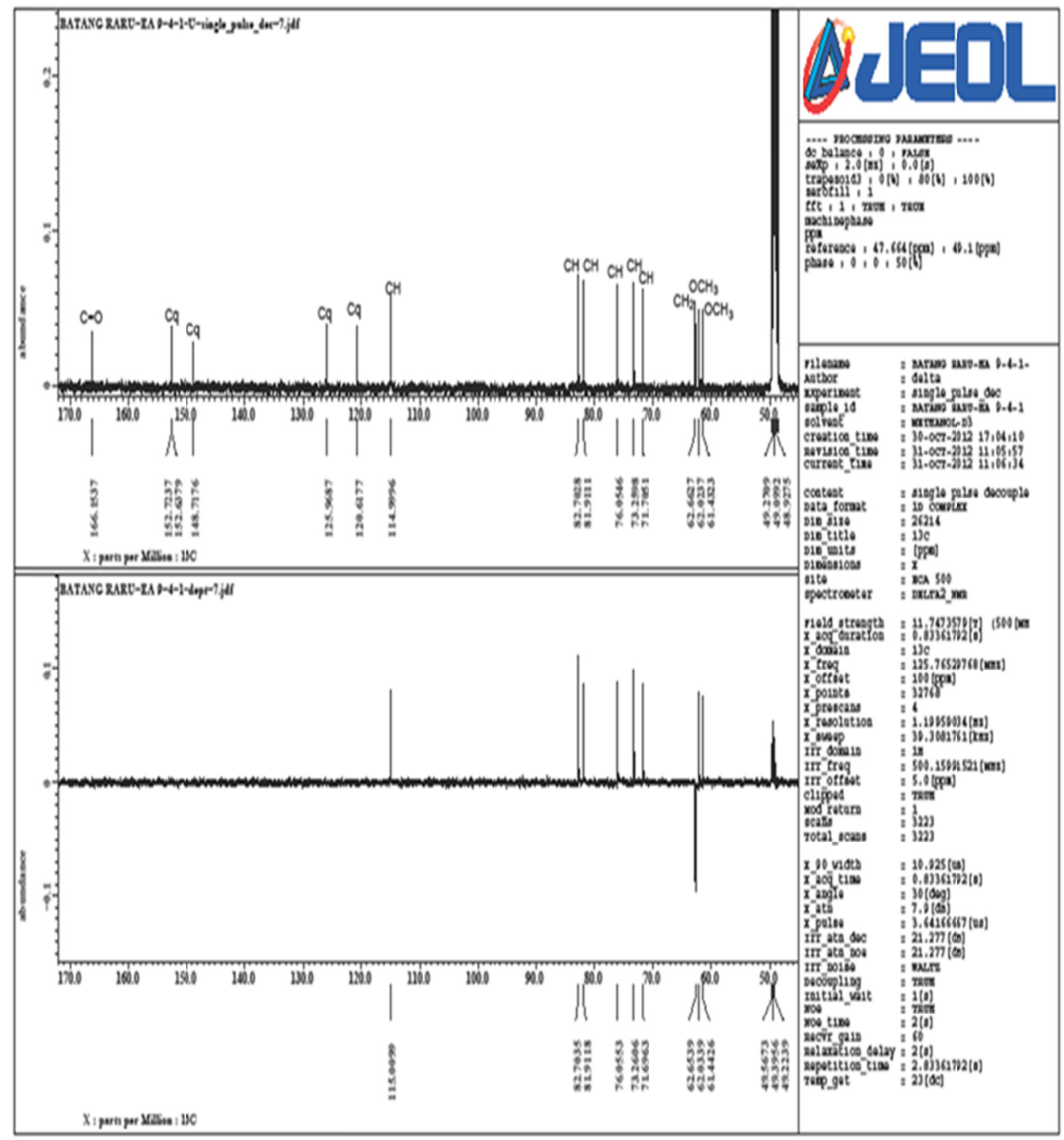

Figure 2. DEPT 13C-NMR spectrum of isolates

The carbonyl atom located very down field that is at $\delta \mathrm{C} 166.15$ (s). Methoxy peaks are at $\delta \mathrm{C} 61.43(\mathrm{q})$ and 62.02 
(q). The presence of the chemical shift in the high field region is about $\delta \mathrm{C} 62.6(\mathrm{t})$ and 71.71 (d), 73.26 (d), 76.05 (d), 81.91 (d), 82.70 (d ), all of which resonate carbon atoms with oxygen atoms. And for the aromatic carbon present in $\delta C 115.00$ (d), 120.62 (s), 125.97 (s), 148.72 (s), 152.64 (s) and 152.72 (s). The relationship between carbon and proton in the ethanol extract of the isolates showed no association between the signal and the carbon nucleus on the same proton. Spot spectrum indicates the two are directly related to the bond. Proton signal at $\delta \mathrm{H}$ $3.79 \mathrm{ppm}$ seen (H1-13) and $\delta \mathrm{H} 3.99$ (H2-13). C-12 at $\delta \mathrm{C} 73.26$ with $\delta \mathrm{H} 4.80(\mathrm{H}-12), \mathrm{C}-3$ at $\delta \mathrm{C} 115.00$ with $\delta \mathrm{H}$ $7.32(\mathrm{H}-3)$.

The relationship between protons and protons in the chemical structure of 9-4-4-1 isolates appear from analysis of COSY spectra. The correlation suggests that the protons of methylene $\left(\mathrm{CH}_{2}\right) \delta \mathrm{H} 3.79(\mathrm{H1}-13)$ and 3.99 $(\mathrm{H} 2-13)$ associated with the proton at $\delta \mathrm{H} 4.80(\mathrm{H}-12) ; \delta \mathrm{H} 4.80(\mathrm{H}-12)$ with $\delta \mathrm{H} 3.96(\mathrm{H}-11)$. Likewise $\delta \mathrm{H} 3.53$ (H-10) with $\delta \mathrm{H} 3.82$ (H-9); $\delta \mathrm{H} 3.82$ (H-9) with $\delta \mathrm{H} 3.54$ (H-8).

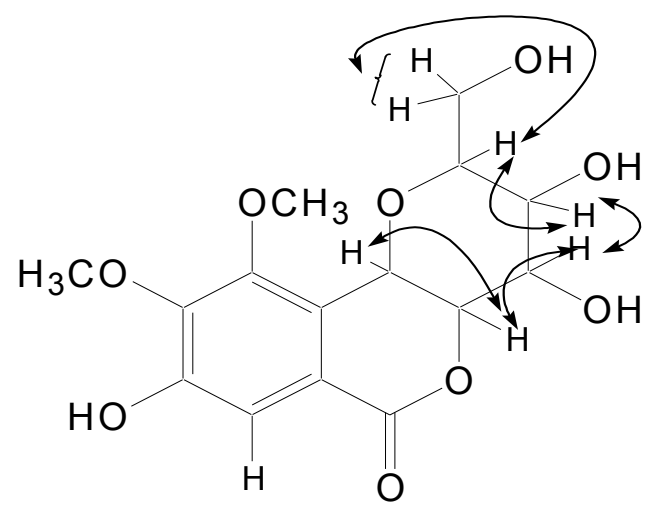

Figure 3. Cosy spectra analysis results for isolates chemical structure 9-4-4-1

The results of the analysis of HMBC spectra of carbon visible at the position C-1 ( $\delta \mathrm{C} 166.15) \mathrm{C}-2$ ( $\delta \mathrm{C} 125.97)$, C-4 $(\delta C$ 152.64), C-5 ( $\delta \mathrm{C} 152.72)$ and C-7 ( $\delta \mathrm{C} 120.62)$. The existence of long-range HMBC Correlation of the spectra looks like Figure 3.

Chemical shifts for proton and carbon chemical structure isolates 9-4-4-1 shown in Figure 4.

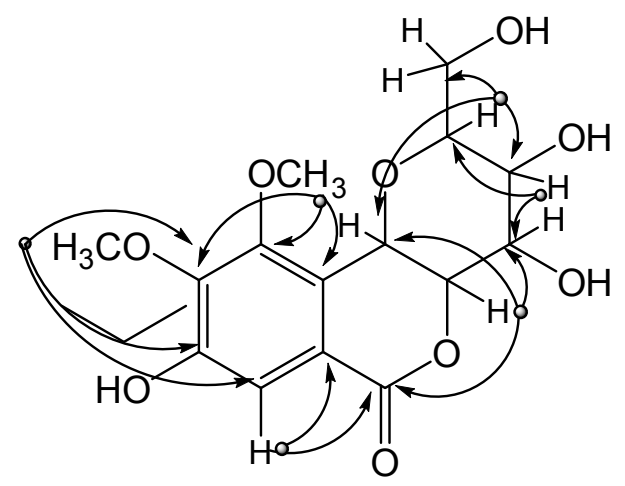

Figure 4. Isolates chemical structure 9-4-4-1 HMBC analysis results 


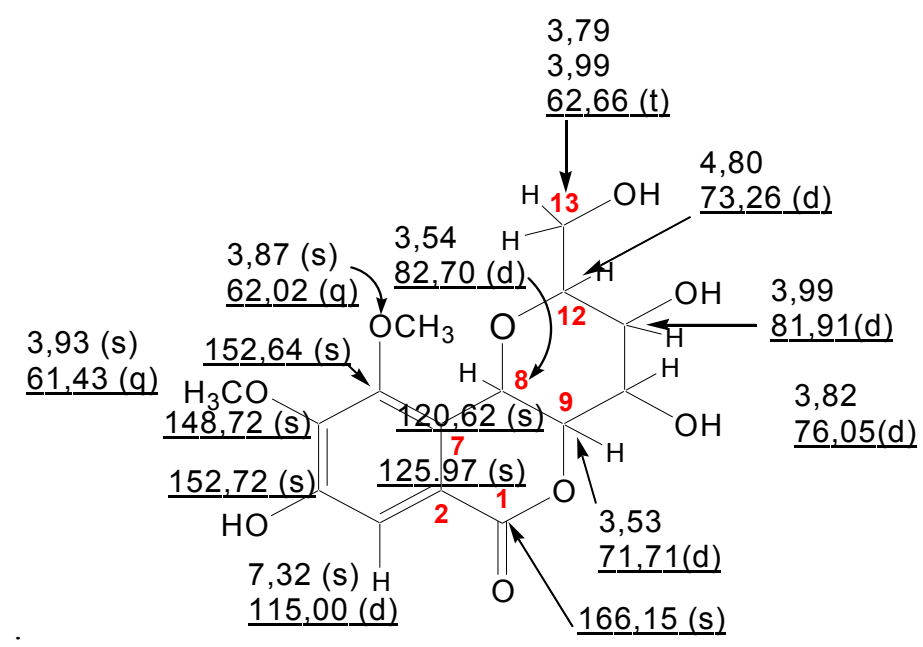

Figure 5. Proton and carbon chemical shifts for chemical structure isolates 9-4-4-1

Carbon chemical shift data for the proton and the chemical structure of 9-4-4-1 isolates presented in Table 3 below.

Table 3. Carbon chemical shift correlation and H-13 C NMR to isolate 9-4-4-1 based on 2D NMR HMQC

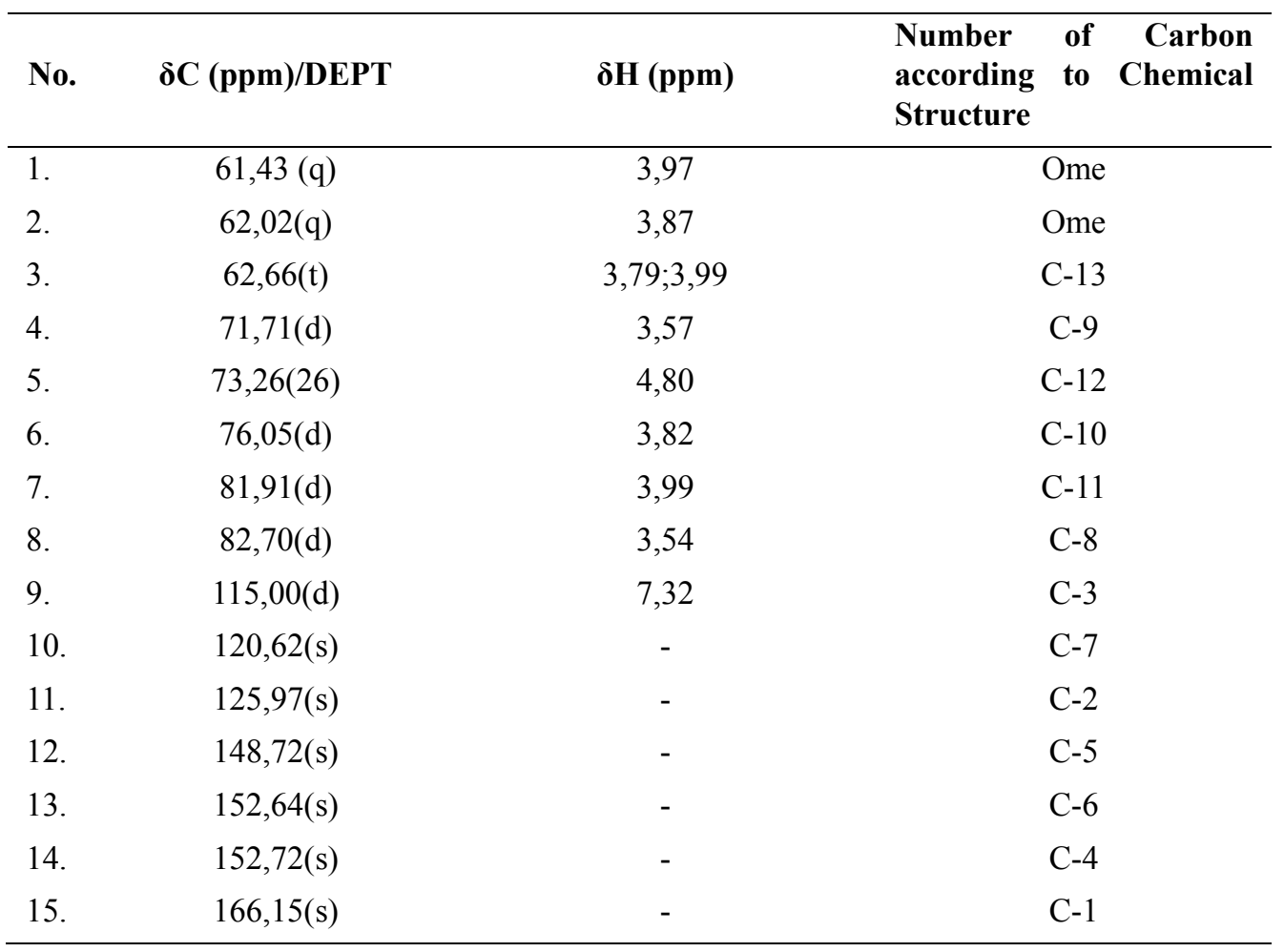

Analysis of mass spectroscopy (MS) is conducted by the HR-MS (High Resolution Mass Spectroscopy) instrument, showed a molecular ion at $\mathrm{m} / \mathrm{z} 342(\mathrm{M})+$. This indicates isolates 9-4-4-1 has a Molecular Weight $(\mathrm{MW}=342)$ for the molecular formula mass $\mathrm{C}_{15} \mathrm{H}_{18} \mathrm{O}_{9}$. Spektra isolate compounds 9-4-4-1 gave molecular ion peaks and fragment ions in the spectra of $\mathrm{m} / \mathrm{z}: 32 ; 265 ; 165$ and 121.

\section{Conclusions}

Isolation and structure elucidation of chemical that has activity as an inhibitor of $\alpha$-glucosidase enzyme from the stem bark raru (Vatica pauciflora Blume) concluded that, (1) Bark raru efficacious as antidiabetic. Inhibit the 
activity of the enzyme $\alpha$-vitro glucosidase by VpEt fraction 9-4-4-1, that is equal to IC50 93.46. (2) The chemical structure of spectral data based on UV-Vis spectrophotometer, FT-IR and NMR spectrometer and proton carbon Nuclear Magnetic Resonance (COSY, HMQC, and HMBC); HRMS isolates obtained VpEt 9-4-4-1 is bergenin dimethoxy compound. The isolate is a acording to International Union of Pure and Applied Chemistry (IUPAC).

\section{References}

Adebayo, A. G. (2008). Inventory of antidiabetic plants in selected districts of lagos State, Nigeria.Departemenof Pharmacognosy, Faculty of Pharmacy, Olabisi Onabanjo University, Sagamu Campus, Ogun State, Nigeria.

Bahar, A., Tawfeq, A., Jaber, S., Mossa., \& Kehel, T. (2005). Isolation antihipertensive activity and Structureactivity Reltionship of flavonoids from three medicinal Plants. Departemen of Pharmacology, College of Pharmacy. Saudi Arabia.

Gunawan, T. P. (2009). Zat Ekstraktif Kayu Raru dan Pengaruhnya Terhadap Penurun Kadar Gula Darah secara invitro. IPB Bogor.

Guyton, A. C., \& Hall, J. E. (1997). Buku Ajar FisiologiKedokteran.Edisi 9. Penerbit Buku Kedokteran ECG. Jakarta.

Hedi, R. D. (2007). Pengembangan Obat Tradisional Indonesia Menjadi Fitofarmaka. Majalah kedokteran, 57(7). Dept. Farmakologi Fakultas Kedokteran UI Jakarta.

Lucile, W. B., \& Dzulkarnain, S. (1997). Tanaman Obat Untuk Diabetes Melitus. Pusat Penelitian dan Pengembangan Kesehatan Departemen Kesehatan RI. Jakarta.

Matsui, T., Ueda, T., Oki, T., Sugita, K., Terahara, N., \& Matsumoto, K. (2001). Alpha Glucosidase Inhibitory Action of Natural Acylated Anthocyanin. Journal Agriculture Food Chemical, 49(4), 1948-1951. http://dx.doi.org/10.1021/jf001251u

Puspa, D. N., Lotulung., Fajriah S., Hanafi M., Sundowo A., \& Filaila E. (2008). Identification of Antidiabetic Flavanone Compound from the Leaves of Artocarpus communis. Research Center for Chemistry, Indonesian Institut Sciences. PUSPITEK. Tangerang Banten.

Riris, I. D., Barus, T., Basuki, W. S., \& dan Partomuan, S. (2013). Aktivitas Antidiabet dan Uji Toksisitas dan Antioksidan dari Ekstrak n-Heksan, Etil Asetat, Etanol, dan Air dari Kulit Batang Raru (Vatica pauciflora Blume). Program Studi Ilmu Kimia Pascasarjana Universitas Sumatera Utara. USU Press.

Steven, M., \& Molyneux, R. (1993). Bioaktive Natural Products. CRC Press Boca Raton Ann Arbor London Tokyo. 1985, H3-14.

World Health Organization (WHO). (2005). Quality Control Methods for Medical Plant Materials. Geneva.

\section{Copyrights}

Copyright for this article is retained by the author(s), with first publication rights granted to the journal.

This is an open-access article distributed under the terms and conditions of the Creative Commons Attribution license (http://creativecommons.org/licenses/by/3.0/). 